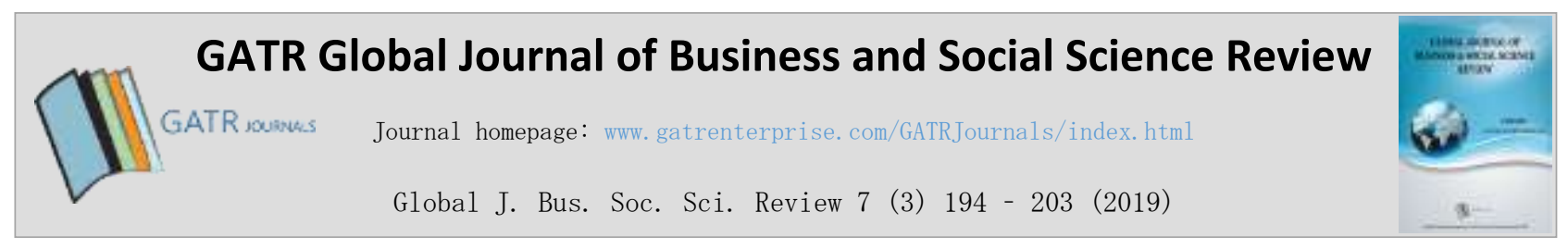

\title{
Halal Food Purchase Behavior of Students from Three School Levels Using Theory of Planned Behavior Approach
}

\author{
Megawati Simanjuntak ${ }^{a}$, Filza Nasiha ${ }^{b}$ \\ ${ }^{1,2}$ Department of Family and Consumer Sciences, Faculty of Human Ecology, University, Bogor, Indonesia.
}

\begin{abstract}
Objective - Food products are diverse in Indonesia. However, there are still numerous products have not certified as halal food. It becomes a challenge, especially for children who cannot adopt a decision with full consideration. This research aims to analyze knowledge, attitude, subjective norms, behavioral control, purchase intention, and purchase behavior differences among students from every level (elementary school, junior school, and senior high school). Furthermore, this research also aims to analyze the influence of knowledge, attitude, subjective norms, and behavioral control toward purchase intention and the influence of knowledge, attitude, subjective norms, behavioral control, and purchase intention toward a purchase behavior.

Methodology/Technique - The research conducted as quantitative research through a self-administered survey on 207 students from elementary school, junior school, and senior high school. The analysis performed SEM.

Finding \& Novelty - The results show that overall, attitude, subjective norms, and behavioral control significantly influence purchase intention and attitude, subjective norms, behavioral control, and purchase intention influence toward a purchase behavior. This finding implies that the role of business and government in facilitating consumers to buy halal food.
\end{abstract}

Type of Paper: Empirical.

Keywords: Halal Food; Knowledge; Purchase Behavior; SEM; Theory of Planned Behavior

Reference to this paper should be made as follows: Simanjuntak, M; Nasiha, F. (2019). Halal Food Purchase Behavior of Students from Three School Levels Using Theory of Planned Behavior Approach, Global J. Bus. Soc. Sci. Review 7 (3): 194 - 203. https://doi.org/10.35609/gjbssr.2019.7.3(4)

JEL Classification: M30, M31, M39.

\section{Introduction}

Indonesia is the fourth most populated country in the world. Most of Indonesia's population are Muslims. This staggering number of people, and the still-growing muslim population in Indonesia, means increased demands of halal food.

\footnotetext{
* Paper Info: Revised: July 19, 2019

Accepted: September 19, 2019

* Corresponding author: Megawati Simanjuntak

E-mail: mega_juntak@apps.ipb.ac.id

Affiliation: Department of Family and Consumer Sciences, Faculty of Human Ecology, IPB University, Bogor, Indonesia.
} 
In Indonesia, the standard of halal food is guaranteed by the country, referring to Law no. 33 the year 2014 concerning Halal product guarantee. Article 1 paragraph 2 from that law said that halal product is a product that has been stated halal according to Islamic law. Islamic law explained that halal means it is allowed, and haram is forbidden. There is an exception for every kind of food and drink that is haram to be consumed by Muslim.

Data from MUI (Indonesian Ulema Council, an organization that published the halal standard) showed that on October 2017, only 2.98 percent product is halal-certified. This number is still low if we see the number of Muslims that should only eat halal food means that Muslims have very limited selection on choosing halal food. With many products that still have not been certified, people need to be more selective when choosing the food, which is why it very important to see the ability of consumer to be selective on what they eat, especially on young consumer. The selective process of product will be more difficult on young consumer. As children cognitive ability is still not as good as adults, and younger consumer still can't decide a purchase with complete consideration.

According to Ajzen (1991), intention described as one's motivation to take action. The intention can be predicted through attitudes toward behavior, subjective norms, and behavior control, which is also known as Theory of Planned Behavior. Maichum et al., (2017) found that the attitude of the consumers has become one of the variables which influence the intention to buy halal food. Otherwise, knowledge of halal food does not affect consumers' purchase intentions. Other research showed that purchase intention of halal cosmetics influenced by knowledge, religiosity, and attitude (Rohmatun \& Dewi, 2017). Kavaliauske and Ubartaite (2014) reported that ethical belief is the utmost important factor indeed influences the purchase intention of organic products of the consumers. Besides, Punnoose (2012) has claimed intention significantly affected by perceived usefulness, subjective norms, and perceived convenience of using the product.

This research focuses on children and adolescent. Calvert (2008) stated that child consumers are difference since children have limited cognitive abilities and skills equal to adults. The results of Triwijayanti's (2012) study showed that children have been able to take consumption decisions independently but not with full consideration. Similarly, Brici et al. (2013) showed that adolescent consumers are more likely to did impulsive buying than adults did. The study explained that impulsive buying behavior often takes place in response to the strain felt by them. Denoth et al. (2011) explained that one of the determinants of adolescent eating behavior in Italy was social constraint from their peers. This means that children consumer are more susceptible to non-halal food rather than adults.

Previous research stated that attitudes toward behavior, subjective norms, and behavioral control significantly influenced the intention to purchase halal food (Alam \& Sayuti 2011). The study did not discuss the effect of these three factors on the purchase of halal food by children who have not been able to consider while food products are increasingly diverse.

This study aimed to analyze the influence of knowledge, attitudes towards behavior, subjective norms, and behavioral control toward purchase intentions and purchase behavior. Prior studies examined factors that influence purchase intention. Conversely, this study emphasis more on the behavior of purchasing halal food using the Theory of Planned Behavior Approach by included the knowledge variable. The subject of this study is an important differentiator with previous studies, namely among children and adolescents.

This research will be beneficial for the educational institution to educate halal food for students. Bussiness also can utilize this research as input in product management and marketing. The government, particularly for the Indonesian Ulema Council, this research become an input in formulating policies or programs regarding the sale and marketing of halal food. 


\section{Literature Review}

\subsection{Effect of knowledge on purchase intention}

Research shows that knowledge, religiosity, and attitudes influence purchase intention (Rohmatun \& Dewi 2017). Shaari and Arifin (2010) found that knowledge is the main factor that influences the purchase intention of halal food. Research conducted by Ginting and Ekawati (2016) shows that knowledge about the environment has a positive and significant influence on the intention to buy green products. Chen et al. (2017) explain that knowledge positively influences purchase intention. This means a person with better knowledge, should have a better intention of buying halal products.

Kusuma and Untarini (2014) found that product knowledge had a significant effect on the shaping of purchase intentions, and also had a significant indirect effect on purchase intention through attitude. In line with that research, the results of other studies on environmentally friendly products show that knowledge has a positive and significant effect on purchase intention. This means that the higher a person's knowledge is, the higher their buying intention is (Suwarso \& Wulandari, 2015). Other research shows that knowledge is the most significant factor in influencing someone's purchase intention (Suki, 2016). In contrast to those previous research, Erida and Rangkuti's (2017) explains that knowledge does not significantly influence someone's purchase intention. It is important to see if knowledge influence someone's purchase intention, as younger consumer usually still don't have a lot of knowledge about halal product, for example the standard of halal products, and what makes the product halal.

Based on empirical studies from Rohmatun and Dewi (2017), Shaari and Arifin (2010), Ginting and Ekawati (2016), Chen et al. (2017), Kusuma and Untarini (2014), Suwarso and Wulandari (2015), Suki (2016), and Erida and Rangkuti (2017) the hypothesis below were formulated:

H1: Knowledge has a significant effect on purchase intention

\subsection{Effect of Attitude toward behavior on purchase intention}

The research of Dwipayani and Rahyuda (2016) shows that attitudes partially have a significant positive effect on the intention to buy online in Denpasar. The results of other studies indicate that the most significant factors that influence consumer purchase intention are consumer attitudes and price perceptions (Jaafar et al., 2013). In line with these findings, the results of research on online promos show that attitudes and normative are affecting consumer purchase intentions (Cheah et al., 2015).

Ali (2017) explained in his research on the purchase intention of halal products in Pakistan that attitudes have a positive influence on the purchase intention of halal food for non-Muslim consumers. Sallam and Algammash (2016) found that consumers' attitudes toward advertising have a positive and significant effect on purchase intention. Maichum et al. (2017) state the same thing as the studies mentioned earlier, that attitude is the most powerful factor and has a direct influence on purchase intention. Which means it very important that consumer has a positive attitude towards halal products, we believe that if the consumer has positive attitude, then it would lead to higher purchase intention on halal products.

Based on a theoretical study from Dwipayani and Rahyuda (2016), Jaafar et al. (2013), Cheah et al. (2015), Ali (2017) and Maichum et al. (2017) hypotheses can be drawn as follows:

$\mathrm{H} 2$ : Attitude toward behavior has a significant effect on purchase intention

(Jaafar et al., 2013; Cheah et al., 2015; Sallam \& Algammash, 2016; Maichum et al., 2017; Dwipayani \& Rahyuda, 2016; Ali, 2017).

\subsection{Effect of Subjective Norms on Purchase Intention}

A study of Yean, Johari, and Sukery (2015) about employee intentions in returning to work proved that subjective norms have a significant effect on intention. Ham, Jeger, and Frajman (2015) also stated that

Global J. Bus. Soc. Sci. Review 7 (3) $194-203$ (2019) 
subjective norms have a significant effect on purchase intention, and Anggelina and Japarianto (2014) showed that subjective norms influence one's intentions.

Research conducted by Ketabi, Ranjbarian, and Ansari (2014) shows that subjective norms directly influence purchase intentions online. In line with the results of these studies, other studies about halal food, also found that subjective norms influence a person's purchase intention (Afendi, Azizan, \& Darami, 2014).

An empirical study from Yean et al. (2015), Ham et al. (2015), Anggelina and Japarianto (2014), Ketabi et al. (2014), and Afendi et al. (2014) explained that subjective norms influence someone's purchase intention, so the hypothesis can be drawn as follows:

H3: Subjective norms have a significant effect on purchase intention

(Anggelina \& Japarianto, 2014; Yean et al., 2015; Ham et al., 2015; Ketabi et al., 2014; Afendi et al., 2014).

\subsection{Effect of Behavioral Control on Purchase Intention}

Wang (2014) stated that behavioral control has an effect on purchase intention so that the higher the control of a person's behavior, the higher the purchase intention of that person towards a product. Maichum et al. (2016) also stated that behavior control influences purchase intention.

The results of the study of Afendi et al. (2014) show that a person's behavioral control has a positive influence on the purchase intention of halal food. Giantari, Zain, Rahayu and Solimun (2013) showed that behavioral control affects the intention to buy online. Research by Huda, Rini, Mardoni, and Putra (2012), Anggelina and Japrianto (2014) showed that behavioral control has a significant effect on purchase intention, so the hypotheses drawn are as follows:

H4: Behavioral control has a significant effect on purchase intention

(Wang, 2014; Maichum et al., 2017; Afendi et al., 2014; Giantari et al., 2013; Huda et al., 2012; Anggelina \& Japrianto, 2014).

\subsection{Effect of Purchase Intention on Purchase Behavior}

Van Hooft Born, Taris, Van der Flier, and Blonk (2005) 's research shows that on job search, intention predicted the job search behavior significantly. Kiriakidis (2015) states that intentions influence behavior, and its relationships tend to be stable under certain conditions.

In the retail industry, the results of research by Cannière et al. (2010) show that the stronger a person's purchase intention is, the higher the possibility of the person to make a purchase. Sheeran and Webb (2016) explain that intention is used as behavior in about half the cases, but the quality of the intention itself greatly influences actual behavior. Based on van Hooft and Born (2005), Kiriakidis (2015), Cannière et al. (2010), and Sheeran and Webb (2016), hypotheses can be drawn as follows:

H5: Purchase intention has a significant effect on purchase behavior

(Van Hooft et al., 2005; Kiriakidis, 2015; Cannière et al., 2010; Sheeran \& Webb, 2016). 
Based on the empirical researches, the framework is presented in Figure 1.

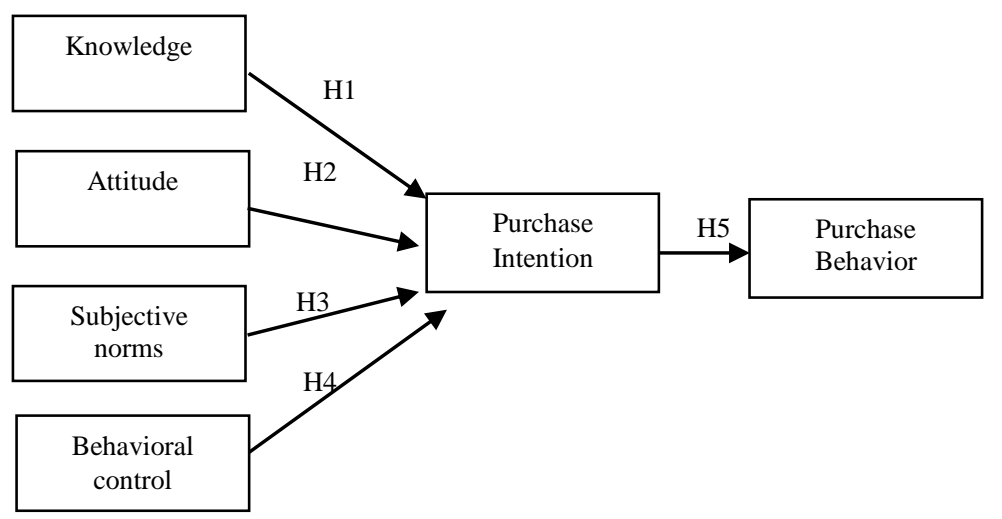

Figure 1. Research framework

\section{Research Methodology}

The study applied quantitative research, conducted in public and private elementary schools, junior schools, and senior high schools in Bogor City. The samples were taken using quota sampling amounted 207 respondents that consisted of 71 elementary school students, 72 junior high school students, and 64 senior high school students. Data were drawn from self-administered questionnaires. The researcher explained how to fill out the questionnaires in advance before the student filled out the questionnaire by themselves.

Endogenous variables in this study are purchase intention and purchase behavior, while exogenous variables are knowledge, attitudes toward behavior, subjective norms, and behavioral control. Knowledge stands for respondents' knowledge of halal food that consists of 20 questions refers to Musdyaningwati (2016) (reliability 0.797). Instruments of attitude towards behavior, subjective norms, and behavioral control adopted from Endah (2014). The instrument of attitudes toward behavior, subjective norms, behavioral control, purchase intentions, and purchase behavior were measured using five Points-Likert scales.

Attitudes toward behavior stand for the evaluation of halal purchasing behavior that consists of eight statements (reliability 0.97). Subjective norm stands for the influence of respondents' reference groups with 11 questions (reliability 0.93). Behavioral control stands for respondents' perception of how far they choose to or not to buy halal food that consists of seven statements (reliability 0.79). Purchase intention relates to the feeling of the buyer and their plan to do a purchase of halal food refers to Maichum et al., (2017) with four statements (reliability 0.85 ). Purchase behavior stands for respondent's activities in purchasing process refers to Murti (2016) with 14 statements (reliability 0.89).

Structural Equation Modelling (SEM) used to analysis that combines the factor analysis approach, structural model, and path analysis. AMOS used to test the whole respondent because AMOS can be used to analyze a lot of data (with the total data used are 207). SmartPLS used to test respondent in every level of education, which is elementary, junior school, and senior high school.

\section{Results}

Based on the goodness of fit test, the RMSEA value of 0.069 means that the model acceptable and included in the good fit category. The GFI value obtained was 0.804 , the CFI value was 0.833 , the IFI value was 0.836 , the RMR value was 0.117 , the AGFI value was 0.767 , and the NFI value was 0.718 included in the marginal fit category. The SEM model used in this study was fit because it meets the RMSEA value as 0.08. This model was obtained after eliminating indicators that have $\mathrm{t}$-value less than 1.96 or $\mathrm{p}$-value more 
than 0.05 . Twenty-one indicators were deleted because the requirements. The eliminating indicators were as follows, six indicators of attitude to behavior, four indicators of subjective norms, two indicators of behavior control, four indicators of purchase intention, and five indicators of buying behavior.

Table 1. The goodness of fit result

\begin{tabular}{llll}
\hline No & Goodness of fit & Cut off value & Result \\
\hline 1. & Root Mean Square Residual (RMR) & $\leq 0.1$ & 0.117 \\
2. & The goodness of Fit Index (GFI) & $\geq 0.90$ & 0.804 \\
3. & Root Mean Square Error of Approximation & $\leq 0.08$ & 0.069 \\
4. & (RMSEA) & $0.80 \leq \mathrm{AGFI}<0.90$ & 0.767 \\
5. & Adjusted Goodness Fit of Index (AGFI) & $\geq 0.90$ & 0.836 \\
6. & Incremental Fit Index (IFI) & $0.80 \leq \mathrm{NFI}<0.90$ & 0.718 \\
7. & Normed Fit Index (NFI) & $\geq 0.90$ & 0.833 \\
\hline
\end{tabular}

The result of SEM analysis to answer hypotheses 1 through 5 was presented in Table 1 . The intention to buy halal food was influenced by all the studied factors with the r-square value as 86.3 percent for elementary school, 75.2 percent for junior high school, 68.8 percent for senior high school, and 86.0 percent for overall level. Halal food purchase behavior was influenced by intention by $r$-square value as 33.4 percent for elementary school, 35.4 percent for junior high school, 46.5 percent for senior high school, and 35.2 percent for overall level.

Based on the SEM test, five hypotheses (H1 to H5) had examined. In elementary and junior high school, only two hypotheses were accepted, while in senior high school, three hypotheses were accepted, and overall, four hypotheses were accepted (Table 2).

Table 2. Hypothesis test result

\begin{tabular}{|c|c|c|c|c|c|c|c|c|}
\hline \multirow{2}{*}{ Path } & \multicolumn{2}{|c|}{ Elementary school } & \multicolumn{2}{|c|}{ Junior high school } & \multicolumn{2}{|c|}{ Senior high school } & \multicolumn{2}{|l|}{ Overall } \\
\hline & Beta & status & Beta & status & Beta & status & Beta & status \\
\hline $\begin{array}{l}\text { Knowledge } \rightarrow \text { Purchase } \\
\text { Intention }\end{array}$ & 0.040 & $\begin{array}{l}\text { Reject } \\
\text { H1 }\end{array}$ & -0.115 & $\begin{array}{l}\text { Reject } \\
\text { H1 }\end{array}$ & -0.005 & $\begin{array}{l}\text { Reject } \\
\text { H1 }\end{array}$ & 0.010 & $\begin{array}{l}\text { Reject } \\
\text { H1 }\end{array}$ \\
\hline $\begin{array}{l}\text { Attitude toward behavior } \rightarrow \\
\text { Purchase Intention }\end{array}$ & -0.047 & $\begin{array}{l}\text { Reject } \\
\mathrm{H} 2\end{array}$ & $0.686 * *$ & $\begin{array}{l}\text { Accept } \\
\mathrm{H} 2\end{array}$ & $0.507 * *$ & $\begin{array}{l}\text { Accept } \\
\mathrm{H} 2\end{array}$ & $0.499 * *$ & $\begin{array}{l}\text { Accept } \\
\mathrm{H} 2\end{array}$ \\
\hline $\begin{array}{l}\text { Subjective norm } \rightarrow \text { Purchase } \\
\text { Intention }\end{array}$ & $0.856^{* *}$ & $\begin{array}{l}\text { Accept } \\
\text { H3 }\end{array}$ & -0.082 & $\begin{array}{l}\text { Reject } \\
\mathrm{H} 3\end{array}$ & 0.083 & $\begin{array}{l}\text { Reject } \\
\text { H3 }\end{array}$ & $0.569 * *$ & $\begin{array}{l}\text { Accept } \\
\text { H3 }\end{array}$ \\
\hline $\begin{array}{ll}\text { Behavioral control } \rightarrow \\
\text { Purchase Intention }\end{array}$ & 0.134 & $\begin{array}{l}\text { Reject } \\
\mathrm{H} 4\end{array}$ & 0.419 & $\begin{array}{l}\text { Reject } \\
\mathrm{H} 4\end{array}$ & $0.424 * *$ & $\begin{array}{l}\text { Accept } \\
\mathrm{H} 4\end{array}$ & $0.536 * *$ & $\begin{array}{l}\text { Accept } \\
\mathrm{H} 4\end{array}$ \\
\hline $\begin{array}{l}\text { Purchase intention } \\
\text { Purchase behavior }\end{array}$ & $0.578 * *$ & $\begin{array}{l}\text { Accept } \\
\text { H5 }\end{array}$ & $0.595 * *$ & $\begin{array}{l}\text { Accept } \\
\text { H5 }\end{array}$ & $0.682 * *$ & $\begin{array}{l}\text { Accept } \\
\text { H5 }\end{array}$ & $0.594 * *$ & $\begin{array}{l}\text { Accept } \\
\text { H5 }\end{array}$ \\
\hline R Square intention & \multicolumn{2}{|l|}{0.863} & \multicolumn{2}{|l|}{0.752} & \multicolumn{2}{|l|}{0.688} & \multicolumn{2}{|l|}{0.860} \\
\hline R Square behavior & \multicolumn{2}{|l|}{0.334} & \multicolumn{2}{|l|}{0.354} & \multicolumn{2}{|l|}{0.465} & \multicolumn{2}{|l|}{0.352} \\
\hline
\end{tabular}

Note: *significant on $\mathrm{p}<0.05 ; * *$ significant on $\mathrm{p}<0.01$

\section{Discussion}

\subsection{The Effect of Knowledge toward Purchase Intention}

Knowledge proved to have no significant effect on halal food purchase intention (p-value $>0.05$ ), revealing that people with more knowledge do not necessarily determine a person's purchase intention towards halal 
food increased. The value means that H1 is rejected; the finding is in line with Erida and Rangkuti (2017) research that has been mentioned above, that knowledge does not have a significant effect on purchase intention. The result applied to every school level. However, the result is in contradict with Shaari and Arifin (2010), who found knowledge as the primary point that affects halal food purchase intention, and research by Chen et al., (2017) who stated that knowledge significantly affects purchase intention positively.

\subsection{The Effect of Attitude Toward Behavior toward Purchase Intention}

The attitude significantly affects purchase intention (p-value $<0.05)$ on the level of junior and senior high school and in general, thus $\mathrm{H} 2$ is accepted. The approved hypothesis reveals that the halal food purchase intentions conducted by respondents based on their evaluation and perception of halal food. Maichum et al. (2017) also discovered that attitude is the most influential factor that has a direct effect on purchase intention. The second hypothesis (H2) in elementary school is rejected since the p-value more than 0.05 . Oppositely with Maichum et al., (2017) and Jaafar et al., (2013) studies, which stated attitude as the most significant factor that affects purchase intention.

\subsection{The Effect of Subjective Norms toward Purchase Intention}

The p-value more than 0.05 means that $\mathrm{H} 3$ is rejected, on junior school and senior high school level. Contrarily, Yean et al., (2015) and Ham et al., (2015) stated subjective that norm has significant effect toward purchase intention. In elementary school level and general, H3 is accepted (p-value $<0.05$ ) and this finding supported by Yean et al., (2015) and Ham et al., (2015) study. Similarly, Afendi et al., (2014) found subjective norm as one of the factors that affect purchase intention, showing that pressure from parents, teachers, and friends influences the purchase intention of elementary school respondents.

\subsection{The Effect of Behavioral Control on Purchase Intention}

The result does not show any significant effect on elementary and junior school level (p-value $>0.05$ ); therefore, H4 is rejected. This is not in line with research done by Wang (2014) who found the higher somebody's behavioral control is, the higher their purchase intention towards the product. However, in senior high school level students and in general, behavioral control has a significant effect on purchase intention (pvalue $<0.5$ ), thus $\mathrm{H} 4$ is accepted within this level. Respondents thought that they were able to purchase halal food, and this opinion affected their buying intentions. These are in line with Giantari et al., (2013) which stated how behavioral control affected the purchase intention online, and Huda et al. (2012) who also stated behavioral control have significant effect towards purchase intention.

\subsection{The Effect of Purchase Intention toward Purchase Behavior}

In general, and on every school level (elementary, junior, and senior high school), the p-value is lower than 0.05. This finding shows that purchase intention has a significant effect on purchase behavior; in other terms, H5 is accepted. In summary, the finding indicated that the higher the purchase intention is, then the higher their purchase behavior. Likewise, Kiriakidis (2015) found that purchase intention has an effect on purchase behavior, and the relationship tends to be stable. The result also follows Cannière et al., (2010), Sheeran and Webb (2016), and also van Hooft et al., (2005) mentioned purchase intention significantly affecting purchase behavior.

Attributed to the research results, some recommendations were given for elementary students, social support from parents, family, and friends in purchasing halal food are needed. As for the junior and senior high school students, it is recommended to guide their preference towards halal food and, increase the ability to buy halal food for senior high school students. The results indicate that there is a need to have the role of 
business actors in facilitating consumers to buy halal food. The role of the government as a policymaker is needed in ensuring the halal food products circulating in the market. The role of parents and teachers as part of the social environment of students is also needed in guiding students to purchase halal food.

The limitation of this research is the use of a self-administered survey that done directly or offline. There is also a limitation of time and sources of the researcher. Hence the researcher cannot make sure if the respondent has answered the whole question, or there is missed the unanswered question. These limitations can lead to invalid data and unfulfilled questionnaire.

\section{Conclusion}

The result of the SEM model shows there was no significant effect of knowledge on intention in every level of school and overall. This means that knowledge does not necessarily determine the consumer purchase intention towards halal food. Meanwhile, there was a significant effect in attitude toward behavior on purchase intention, and this can be found on every level of school. Halal food purchase intentions are based on the evaluation and perception of halal food. A significant effect of subjective norm toward purchase intention can only be found on elementary school and in overall, while a significant effect of behavioral control towards purchase intention can be found on senior high school level and in overall. It means that pressure from parents, teachers, and friends will increase the purchase intention of elementary school students. The higher the behavioral control is, the higher the purchase intention towards the product. A significant effect of purchase intention toward purchase behavior can be found on all school level and overall. Means that the higher the purchase intention is, then the higher the purchase behavior toward halal food.

In this research, some data were not valid because of incompleteness while filling the survey. In a future study, it is better to do collect data more efficiently, so there will be no invalid data. Efficiency can also be done in term of time and human resources of the researcher.

Some recommendation needs to implement to increase the students' halal food buying behavior. For elementary students, social support from parents, family, and friends is needed in purchasing halal food. Junior school students are advised to increase their preference for halal food and also increase their ability to buy halal food for senior high school students. The results of the study indicate the need for the role of businesses in facilitating consumers to buy halal food. The role of the government as a policymaker is also very much needed in ensuring the halal of food products circulating in the market. The role of parents and teachers as part of the social environment of students is also needed in guiding students to purchase halal food.

In the future, research on factors that influence the intention and behavior of halal food purchases can be extended, such as brand image, advertisements, celebrity endorsers, brand trust, or other variables. Researchers can also analyze the effect of knowledge on buying behavior through attitude. The selfadministered survey technique can be further conditioned by regulating the number of respondents and the position of filling out questionnaires in the classroom. Random sampling can be used in determining samples so that research results can be generalized.

\section{References}

Afendi, N. A., Azizan, F. L., \& Darami, A. I. (2014). Determinants of halal purchase intention: case in Perlis. International Journal of Business and Social Research, 4(5), 118-123. http://dx.doi.org/10.18533/ijbsr.v4i5.495

Ajzen, I. (1991). The theory of planned behavior. Organizational behavior and human decision processes, 50(2), 179211. https://doi.org/10.1016/0749-5978(91)90020-T

Ali, A. (2017). Halal Products Purchase Intention in Pakistan: Evidences from Non-Muslim Community. Arabian Journal of Business and Management Review, https://pdfs.semanticscholar.org/efd7/264874df2f9c4cc5519ff1fe9a9ed662715f.pdf 
Anggelina, J., \& Japarianto, E. (2014). Analysis of the Effect of Attitude, Subjective Norm, and Perceived Behavioral Control on SOGO Department Store's Purchase Intention at Tunjungan Plaza Surabaya. Jurnal Strategi Pemasaran, 2(1). Online: http://publication.petra.ac.id/index.php/manajemen-pemasaran/article/view/1351

Brici, N., Hodkinson, C., \& Sullivan-Mort, G. (2013). Conceptual differences between adolescent and adult impulse buyers. Young Consumers, 14(3), 258-279. https://doi.org/10.1108/YC-01-2013-00340

Statistik, B. P. (2017). Indeks Pembangunan Manusia 2016. Jakarta (ID): Badan Pusat Statistik. http://ppid.barrukab.go.id/wp-content/uploads/2017/08/IPM-2015-min.pdf

Calvert, S. L. (2008). Children as consumers: Advertising and marketing. The future of children, 18(1), 205-234. https://doi.org/10.1353/foc.0.0001

De Cannière, M. H., De Pelsmacker, P., \& Geuens, M. (2009). Relationship quality and the theory of planned behavior models of behavioral intentions and purchase behavior. Journal of business research, 62(1), 82-92. https://doi.org/10.1016/j.jbusres.2008.01.001

Cheah, I., Phau, I., \& Liang, J. (2015). Factors influencing consumers' attitudes and purchase intentions of e-deals. Marketing Intelligence \& Planning, 33(5), 763-783. https://doi.org/10.1108/MIP-05-2014-0081

Dwipayani, N. M., \& Rahyuda, I. K. (2016). Effect of attitude and fashion leadership on purchase intentions. Consumer Journal, 9(3). 363-382, https://doi.org/10.1108/13612021111151941

Endah, N. H. (2014). Purchasing Behavior of Halal Labeled Cosmetics by Indonesian Consumers. Jurnal Ekonomi dan Pembangunan, 22(1), 25-39. http://dx.doi.org/10.14203/JEP.22.1.2014.25-39

Erida, E., \& Rangkuti, A. S. (2017). The Effect of Brand Image, Product Knowledge and Product Quality on Purchase Intention of Notebook with Discount Price as Moderating Variable. Journal of Business Studies and Management Review, 1(1), 26-32. https://doi.org/10.22437/jb.v1i1.3919

Giantari, I. G. A. K., Zain, D., Rahayu, M., \& Solimun, M. (2013). The role of perceived behavioral control and trust as mediator of experience on online purchasing intentions relationship a study on youths in denpasar city (Indonesia). International Journal of Business and Management Invention, 2(1), 30-38. https://pdfs.semanticscholar.org/0171/d406f8c42796ae5ef8d3de3b0eb12b918dc6.pdf

Ginting, R. K., \& Ekawati, N. W. (2016). Effect of Environmental Knowledge on the Intention of Buying Green Products on "Attack" Brands with Environmental Concerns as Mediation Variables. E-Jurnal Manajemen Unud, 5(4): 2223 - 2249. Retrieved from https://ojs.unud.ac.id/index.php/Manajemen/article/view/18274

Ham, M., Jeger, M., \& Frajman Ivković, A. (2015). The role of subjective norms in forming the intention to purchase

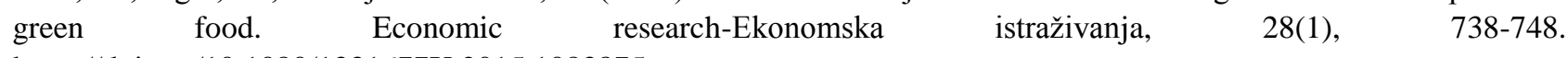
https://doi.org/10.1080/1331677X.2015.1083875

Huda, N., Rini, N., Mardoni, Y., \& Putra, P. (2012). The analysis of attitudes, subjective norms, and behavioral control on muzakki's intention to pay zakah. International Journal of business and social science, 3(22). http://www.ijbssnet.com

Jaafar, S. N., Lalp, P. E., \& Naba, M. M. (2012). Consumers' perceptions, attitudes and purchase intention towards private label food products in Malaysia. Asian Journal of Business and Management Sciences, 2(8), 73-90. www.ajbms.org

Kavaliauske, M., \& Ubartaite, S. (2014). Ethical behaviour: Factors influencing intention to buy organic products in Lithuania. Economics and management, 19(1), 72-83. https://doi.org/10.5755/j01.em.19.1.4991

Ketabi, S. N., Ranjbarian, B., \& Ansari, A. (2014). Analysis of the effective factors on online purchase intention through theory of planned behavior. International Journal of Academic Research in Business and Social Sciences, 4(4), 374-382. http://dx.doi.org/10.6007/IJARBSS/v4-i4/808

Kiriakidis, S. (2015). Theory of planned behavior: The intention-behavior relationship and the perceived behavioral control (PBC) relationship with intention and behavior. International Journal of Strategic Innovative Marketing, 3(2), 40-51. http://dx.doi.org/10.15556/IJSIM.02.03.004

Kusuma, I. D., \& Untarini, N. (2014). Effect of Product Knowledge on Buying Intentions with Attitudes as Intervening Variables. Journal Ilmu Manajemen, 2(4): 1573 - $1583 . \quad$ Retrieved from: https://jurnalmahasiswa.unesa.ac.id/index.php/jim/article/view/11153

Maichum, K., Parichatnon, S., \& Peng, K. C. (2017). The Influence of Attitude. Knowledge and Quality on Purchase Intention towards Halal Food: A Case Study of Weng Non-Muslim Consumers in Thailand, 6(3), 354. http://dx.doi.org/10.21013/jmss.v6.n3.p3

Murti, C. (2016). Knowledge and Awareness of Behavior of Halal Food Purchases (thesis). Bogor Agricultural University, Bogor. 
Musdyaningwati, T. (2016). Relationship between the Level of Knowledge About Halal Food Against the Decision of Purchasing Halal Products at Muhammadiyah University Students in Semarang (thesis). University of Muhammadiyah Semarang, Semarang

Punnoose, A. C. (2012). Determinants of intention to use eLearning based on the technology acceptance model. Journal of Information Technology Education: Research, 11(1), 301-337.Retrieved from: https://www.learntechlib.org/p/111507/

Rohmatun, K. I., \& Dewi, C. K. (2017). The Effect of Knowledge and Religiosity on Intention to Buy in Halal Cosmetics Through Attitude. Ecodemica, 1(1), 27-35. https://doi.org/10.31311/jeco.v1i1.1420

Sallam, M. A., \& Algammash, F. A. (2016). The effect of attitude toward advertisement on attitude toward brand and purchase intention. International Journal of Economics, Commerce and Management, 4(2), 509-520. http://ijecm.co.uk/ Shaari, J. A. N., \& Arifin, M. N. S. (2010). Dimension of halal purchase intention: A preliminary study. In: American Business Research Conference, 28-29 Sept 2009, New York, USA. http://eprints.um.edu.my/id/eprint/11147

Sheeran, P., \& Webb, T. L. (2016). The intention-behavior gap. Social and personality psychology compass, 10(9), 503-518. https://doi.org/10.1111/spc3.12265

Shih, S. P., Yu, S., \& Tseng, H. C. (2015). The Study of consumers' buying behavior and consumer satisfaction in beverages industry in Tainan, Taiwan. Journal of economics, business and management, 3(3), 391-394. https://pdfs.semanticscholar.org/56e0/447eb6ad4d7f80c9f1d7dad6739d922e5e2c.pdf

Mohd Suki, N. (2016). Green product purchase intention: impact of green brands, attitude, and knowledge. British Food Journal, 118(12), 2893-2910. https://doi.org/10.1108/BFJ-06-2016-0295

Suwarso, N. H. E., \& Wulandari, N.M. (2015). Effect of Knowledge and Attitudes on the Purchase Intention of Environmentally Friendly Products (Case Study in Pertamax in Denpasar City). E-Jurnal Manajemen Unud, 4(10): 3119 - 3145. Retrieved from: https://ojs.unud.ac.id/index.php/Manajemen/article/view/14433

Triwijayati, A. (2012). Children's Competence in Taking Consumption Decisions and the Regulation and Empowerment of Child C in Consuming Snack Foods. Journal of Management Applications, 10 (2), 318-328.Retrieved from: https://jurnaljam.ub.ac.id/index.php/jam/article/view/423

Van Hooft, E. A., Born, M. P., Taris, T. W., Van der Flier, H., \& Blonk, R. W. (2005). Bridging the gap between intentions and behavior: Implementation intentions, action control, and procrastination. Journal of Vocational Behavior, 66(2), 238-256. https://doi.org/10.1016/j.jvb.2004.10.003

Wang, Y. (2014). Consumers' purchase intentions of shoes: theory of planned behavior and desired attributes. International Journal of Marketing Studies, 6(4), 50.

Yean, T. F., Johari, J., \& Sukery, A. F. M. (2015). The Influence of Attitude, Subjective Norms, And Perceived Behavioural Control on Intention to Return To Work: A Case Of Socso's Insured Employees. Kajian Malaysia: Journal of Malaysian Studies, 33. Retrieved from: http://web.usm.my/km/33(Supp.1)2015/Art.9\%20(141-154).pdf 